\title{
Kemampuan Koneksi Matematis Siswa Ditinjau dari Kecerdasan
} Intrapersonal

\author{
Fardan Kusumahadi ${ }^{1 *}$, \& Harina Fitriyani ${ }^{2}$ \\ ${ }^{1,2}$ Universitas Ahmad Dahlan, Yogyakarta, Indonesia
}

\section{INFO ARTICLES}

Article History:

Received: 15-02-2021

Revised: 23-05-2021

Approved: 09-06-2021

Publish Online: 30-06-2021

Key Words:

Mathematical Connection Ability; Intrapersonal Intelligence;

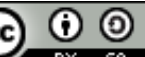 \\ This article is licensed under a Creative Commons Attribution-} ShareAlike 4.0 International License.

\begin{abstract}
This study aimed to describe the mathematical connection capacity of junior high school students with high, medium, and low intrapersonal intelligence in solving triangle and circle problems. The scope of this research includes $8^{\text {th }}$ grade of a state junior high school students in Yogyakarta. The study uses a qualitative approach, with descriptive data analysis of Milles and Huberman's model, including data reduction, data presentation, and conclusion. The results of the study show that subjects with high and low intrapersonal intelligence met all mathematical connection indicators that are, recognizing and connecting between mathematical ideas and applying mathematical concepts in everyday life. While subjects with medium intrapersonal intelligence meet one indicator of mathematical connection, namely recognizing and connecting among mathematical ideas but not complete.
\end{abstract}

\begin{abstract}
Abstrak: Tujuan dari penelitian ini untuk mendeskripsikan kemampuan koneksi matematis pada siswa SMP yang memiliki kecerdasan intrapersonal tinggi, sedang, dan rendah dalam memecahkan masalah segitiga dan lingkaran. Sedangkan ruang lingkup penelitian ini meliputi siswa kelas VII di salah satu SMP Negeri di Yogyakarta. Penelitian ini menggunakan pendekatan kualitatif dengan analisis data deskriptif model Miles dan Huberman yang memuat reduksi data, penyajian data, dan kesimpulan. Hasil penelitian menunjukkan bahwa subjek dengan kecerdasan intrapersonal tinggi dan rendah memenuhi seluruh indikator koneksi matematis yaitu mengenali dan menghubungkan di antara ide-ide matematika, serta mengaplikasikan ide matematika dalam kehidupan sehari-hari. Sedangkan subjek kecerdasan intrapersonal sedang hanya memenuhi satu indikator koneksi matematis, yaitu mengenali dan menghubungkan antar ide-ide matematika tetapi belum lengkap.
\end{abstract}

Correspondence Address: Jln. Ringroad Selatan, Tamanan, Banguntapan, Kabupaten Bantul, DIY, Indonesia; e-mail: fardankusuma98@gmail.com

How to Cite (APA $6^{\text {th }}$ Style): Kusumahadi, F. \& Fitriani, H. (2021). Kemampuan Koneksi Matematika pada Siswa SMP Ditinjau dari Kecerdasan Intrapersonal. JKPM (Jurnal Kajian Pendidikan Matematika), 6(2): 167-178.

Copyright: 2021 Fardan Kusumahadi, Harina Fitriyani

Competing Interests Disclosures: The authors declare that they have no significant competing financial, professional or personal interests that might have influenced the performance or presentation of the work described in this manuscript. 


\section{PENDAHULUAN}

Matematika merupakan ilmu yang membutuhkan keterampilan berpikir dan keterkaitan antar topik, baik di dalam matematika itu sendiri atau dengan bidang lainnya. Keterkaitan ini merupakan bahan kajian pada kemampuan koneksi matematis. Kemampuan koneksi matematis merupakan salah satu dari lima kemampuan dasar yang disarankan dimiliki oleh siswa (NCTM, 2000), yaitu pemecahan masalah (problem solving), penalaran dan bukti (reasoning and proof), komunikasi (communication), koneksi (connection), dan representasi (representation). Kelima kemampuan dasar itu disebut juga daya matematis (Fitriyani, Setyawan, et al., 2021). Dalam pembelajaran matematika, kemampuan koneksi matematis menjadi salah satu kemampuan penting yang harus dikuasai siswa (Prihastanto \& Fitriyani, 2017).

Koneksi matematis dapat diartikan sebagai pengaitan ide-ide matematika, baik antar konsep matematika maupun dengan konsep di bidang lain, serta antara konsep-konsep matematika dengan kehidupan sehari-hari (Romli, 2016). Menurut Widarti (2019) kemampuan koneksi matematis adalah kemampuan siswa dalam mencari hubungan suatu konsep dan prosedur, memahami topik matematika, dan kemampuan siswa dalam mengaplikasikan konsep matematika dalam bidang lain ataupun dalam kehidupan sehari-hari. Selain itu, Muflihah (2019) juga mengemukakan bahwa kemampuan koneksi matematis merupakan kemampuan siswa untuk mengenali, menggunakan, dan menghubungkan konsep-konsep baik konsep dalam matematika maupun konsep di luar matematika sehingga kemampuan koneksi matematis dapat diartikan sebagai suatu kemampuan yang dimiliki oleh siswa dalam menghubungkan suatu konsep matematika baik dengan ilmu matematika, ilmu lain bahkan dengan konteks kehidupan seharihari. Adapun indikator kemampuan koneksi matematis yang digunakan dalam penelitian ini mengadopsi dari indikator kemampuan koneksi matematis menurut NCTM (2000) yaitu a) mengenali dan menghubungkan antar ide-ide matematika; dan b) mengaplikasikan ide-ide matematika dalam kehidupan sehari-hari.

Setiap siswa terlahir dengan kecerdasan yang dimilikinya. Kecerdasan tersebut akan berguna dalam penyelesaian permasalahan baik di kelas maupun di kehidupan nyata. Menurut Budiningsih (2005) terdapat 10 kecerdasan yang dimiliki manusia yakni: kecerdasan verbal, kecerdasan logika, kecerdasan visual, kecerdasan tubuh, kecerdasan musikal, kecerdasan interpersonal, kecerdasan intrapersonal, kecerdasan naturalis, kecerdasan spiritual, dan kecerdasan eksistensial. Kecerdasan yang terkait dengan kemampuan setiap individu memahami dirinya sendiri merupakan kecerdasan intrapersonal (Budiyanta et al., 2019). Individu yang mampu memahami dirinya sendiri cenderung akan mampu memotivasi dirinya dan mampu bertanggung jawab atas dirinya dan kehidupannya. Dalam pembelajaran matematika, siswa yang mempunyai kecerdasan intrapersonal mampu memotivasi dirinya serta mengetahui kelebihan dan kekurangannya (Rokhima \& Fitriyani, 2018). Kecerdasan intrapersonal dapat dikategorikan menjadi tiga yaitu kategori tinggi, sedang dan rendah. Pengkategorian ini didasarkan pada pembagian hasil skor angket kecerdasan intrapersonal siswa dalam satu kelas menjadi tiga kelompok dengan memperhatikan rata-rata dan simpangan bakunya. Oleh karena itu, kecerdasan intrapersonal penting dimiliki siswa dalam pembelajaran matematika agar siswa dapat memahami dirinya dan mengukur kemampuannya dalam memaksimalkan kemampuan koneksi matematis yang dimilikinya pada pemecahan masalah matematika, termasuk masalah geometri.

Pada kurikulum matematika di SMP, geometri diajarkan pada setiap jenjang kelas. Materi segitiga dan lingkaran merupakan salah dua dari bidang kajian geometri yang diajarkan di kelas VII. Kedua materi tersebut banyak keterkaitannya dengan kehidupan sehari-hari. Pada dasarnya, materi segitiga dan lingkaran tidak asing bagi siswa. Sejak kecil siswa sudah dibiasakan mengenal bentuk dan konsep geometri dalam kesehariannya, seperti bentuk roda sepeda, tiang penyangga jembatan berbentuk segitiga, bahkan mainan yang menyerupai bentuk segitiga atau lingkaran, maupun bentuk-bentuk bangun geometri lainnya. Namun sayangnya, siswa masih kesulitan dalam 
menyelesaikan soal geometri sebagaimana tampak pada hasil Ujian Nasional SMP dalam kurun lima tahun terakhir (2015-2019) menunjukkan rata-rata capaian belajar geometri yang masih rendah dibandingkan dengan rata-rata capaian belajar cabang matematika lainnya, yaitu rata-rata Geometri dan pengukuran 46,28; bilangan 49,83; Aljabar 50,39; Statistika dan Peluang 53,04 (Kemendikbud, 2019). Beberapa penelitian menemukan kemungkinan letak kesulitan siswa yaitu siswa tidak memahami apa yang dimaksud soal, siswa bingung menggunakan rumus yang diperlukan, dan kesalahan siswa menggunakan operasi hitung (Zuyyina et al., 2018). Selain itu, kesulitan siswa juga terletak pada rendahnya kemampuan siswa menerapkan konsep geometri pada pemecahan masalah dalam dunia nyata (Anjani \& Imami, 2019). Keterampilan menghubungkan konsep geometri dengan masalah dunia nyata ini merupakan salah satu bagian dari kemampuan koneksi matematis.

Kemampuan koneksi matematis siswa dalam menyelesaikan masalah geometri menjadi menarik untuk dikaji lebih dalam, apalagi bila dikaitkan dengan kecerdasan intrapersonal siswa. Siswa yang memiliki kecerdasan intrapersonal cenderung mampu memahami potensi dirinya sehingga diharapkan siswa dapat memanfaatkan kemampuan koneksi matematisnya dalam pemecahan masalah matematika. Sejauh yang diketahui, belum banyak dijumpai penelitian yang berfokus kepada kemampuan koneksi matematis siswa dan kecerdasan intrapersonal, khususnya bagi siswa SMP. Kemampuan koneksi matematis siswa SMP telah diteliti pada materi lingkaran (Zuyyina et al., 2018), persamaan dan pertidaksamaan linear satu variabel (Padillah Akbar, 2018), aljabar (Mumu \& Tanujaya, 2019), dan materi bangun ruang sisi datar (Lestari et al., 2018). Sedangkan Apipah (2018) meneliti kemampuan koneksi matematis siswa SMP berdasarkan gaya belajar visual auditori kinestetik. Selain siswa sebagai subjek penelitian, kemampuan koneksi matematis juga diteliti dari persepsi guru dan pengalamannya dalam pembelajaran (Siregar \& Siagian, 2019). Sedangkan terkait dengan kecerdasan intrapersonal, Rokhima \& Fitriyani (2017) telah melakukan penelitian yang fokus pada kecerdasan intrapersonal siswa pada kemampuan pemecahan masalah dan kemampuan metakognisi (Rokhima \& Fitriyani, 2018). Penggabungan kedua topik, kemampuan koneksi matematis dan kecerdasan intrapersonal, menjadi bahasan yang jarang diteliti. Siswa yang mampu memahami kemampuannya dan mampu memotivasi dirinya diharapkan akan mampu mengoptimalkan potensinya dalam memecahkan masalah geometri terutama yang membutuhkan keterampilan mengkoneksikan ide-ide matematika maupun di luar topik matematika.

Berdasarkan paparan di atas, penelitian ini bertujuan untuk mendeskripsikan kemampuan koneksi matematis siswa kelas VII SMP dalam memecahkan masalah geometri untuk materi segitiga dan lingkaran pada siswa yang memiliki perbedaan tingkat kecerdasan intrapersonal. Penelitian ini penting dilakukan untuk menggali kemampuan koneksi matematis siswa dari beragam kecerdasan intrapersonalnya. Hasil penelitian ini diharapkan dapat menjadi bahan pertimbangan guru dalam menyusun skenario pembelajaran geometri, menyusun soal geometri serta menambah referensi guru tentang kemampuan koneksi matematis siswa dan kecerdasan intrapersonal siswa dalam pembelajaran geometri.

\section{METODE}

Penelitian ini menggunakan pendekatan deskriptif kualitatif dan dilakukan pada siswa kelas VII di salah satu SMP Negeri di Yogyakarta yang dipilih dengan teknik purposive sampling. Pengambilan data dilakukan pada semester genap tahun ajaran 2019/2020. Teknik pengumpulan data menggunakan angket, tes tertulis dan wawancara. Instrumen penelitian yaitu peneliti, angket kecerdasan intrapersonal, soal tes kemampuan koneksi matematis dan pedoman wawancara. Angket kecerdasan intrapersonal diberikan secara online menggunakan google form. Angket kecerdasan intrapersonal mengadopsi angket yang telah dikembangkan oleh Rokhima \& Fitriyani (2017) yang terdiri dari 40 pernyataan dengan empat pilihan jawaban yaitu yaitu Sangat Sesuai 
(SS), Sesuai (S), Tidak Sesuai (TS) dan Sangat Tidak sesuai (STS). Angket ini digunakan untuk memetakan kecerdasan intrapersonal siswa yang kemudian dipilih masing-masing satu siswa kategori tinggi, sedang dan rendah sebagai subjek penelitian. Pemilihan subjek penelitian dengan meminta pertimbangan guru matematika terutama terkait kemampuan siswa dalam berkomunikasi.

Soal tes kemampuan koneksi matematis berbentuk uraian yang terdiri dari dua butir soal geometri materi segitiga dan lingkaran sebagaimana disajikan pada Gambar 1. Berdasarkan pembagian tipe masalah matematika menurut Burte (2020) maka soal yang digunakan termasuk tipe visual problem dengan abstract context untuk soal nomor satu dan konteks real-world untuk soal nomor dua. Adapun wawancara yang digunakan yaitu wawancara tidak terstruktur. Untuk mendapatkan data penelitian yang valid digunakan triangulasi teknik. Analisis data menggunakan model Miles dan Huberman yaitu reduksi data, penyajian data dan penarikan kesimpulan (Miles et. al., 2014).
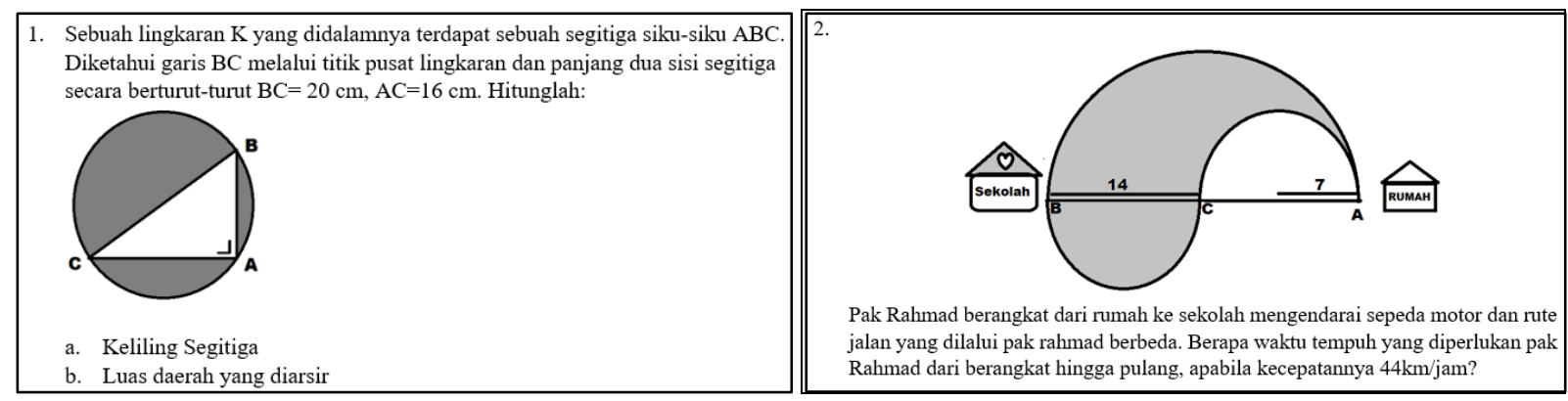

\section{Gambar 1. Soal Tes Kemampuan Koneksi Matematis}

\section{HASIL}

Angket kecerdasan intrapersonal diberikan kepada 35 siswa kelas VII di sekolah tempat penelitian tetapi hanya 31 siswa bersedia mengisi angket yang terdiri dari 16 siswa laki-laki dan sisanya siswa perempuan. Dari hasil angket kecerdasan intrapersonal diperoleh skor terrendah 112, skor tertinggi 156, nilai rata-rata 136,4 dan simpangan bakunya adalah 11,06. Hasil pemetaan kecerdasan intrapersonal siswa menunjukkan bahwa kecerdasan intrapersonal siswa di kelas beragam dari kategori tinggi, sedang, dan rendah sebagaimana tersaji pada Gambar 2.

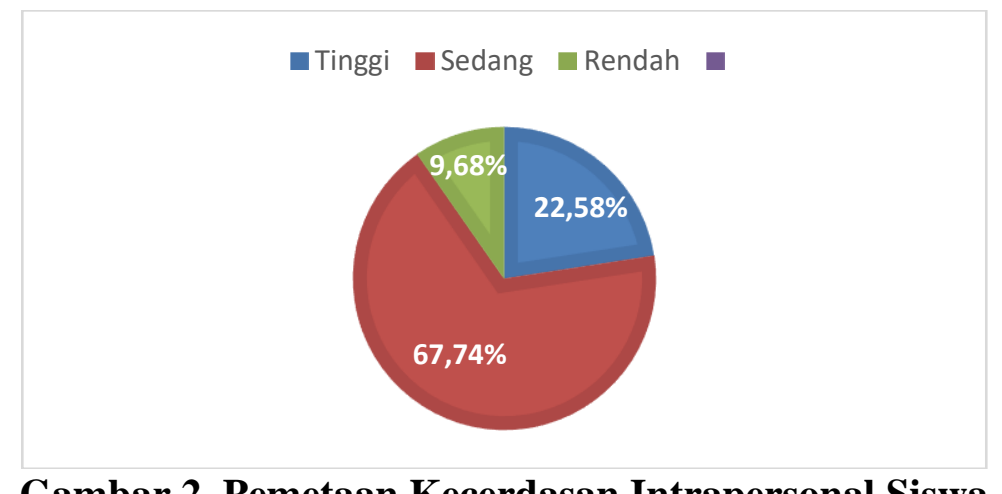

\section{Gambar 2. Pemetaan Kecerdasan Intrapersonal Siswa}

Dari Gambar 2 menunjukkan bahwa kecerdasan intrapersonal siswa didominasi pada kategori sedang yaitu $67,74 \%$. Hal ini menunjukkan bahwa sebagian besar siswa memiliki kemampuan memahami dirinya sendiri dengan baik. Temuan ini sejalan dengan temuan penelitian Rokhima dan Fitriyani (2018) yang menunjukkan bahwa kecerdasan intrapersonal siswa SMP 
didominasi kategori sedang (67\%) dan temuan Budiyanta dkk (2019) yang menunjukkan bahwa sebagian besar siswa SMP $(71,74 \%)$ memiliki kecerdasan intrapersonal kategori sedang.

Subjek terpilih dari masing-masing kategori kecerdasan intrapersonal yaitu ST (kecerdasan intrapersonal tinggi), SS (kecerdasan intrapersonal sedang), dan SR (kecerdasan intrapersonal rendah). Jawaban subjek penelitian ST, SS, dan SR pada pengambilan data tes tertulis disajikan pada Gambar 3., Gambar 4., dan Gambar 5.

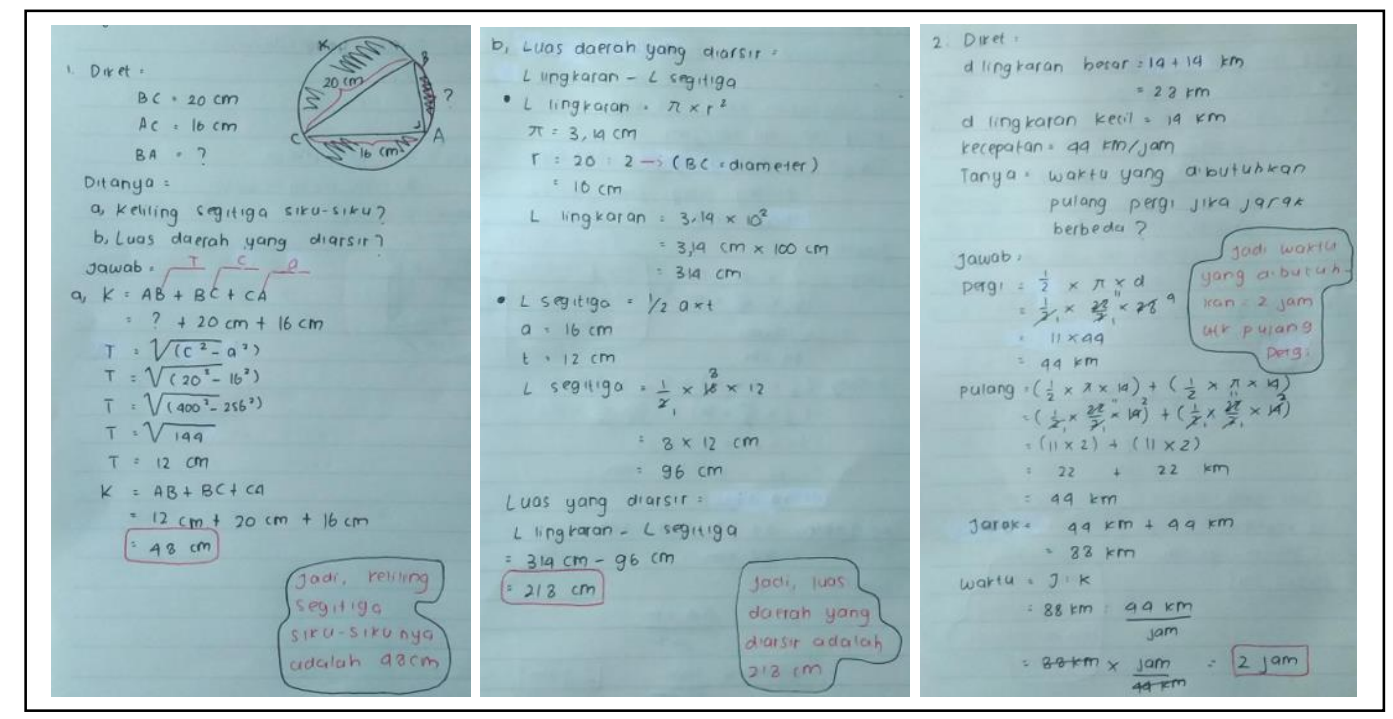

Gambar 3. Hasil Jawaban Tes Tertulis Subjek ST

Hasil tes tertulis subjek ST sebagaimana pada Gambar 3 menunjukkan bahwa ST mampu mengenali ide-ide matematika dengan baik. Pada soal nomor 1, subjek ST mampu menghubungkan antar ide-ide geometri dalam pemecahan masalah yaitu ide tentang konsep keliling dan luas daerah segitiga dan lingkaran. Pada soal nomor 2, subjek ST mampu memahami soal dengan baik dan mengaplikasikan ide-ide tentang konsep keliling lingkaran ke dalam pemecahan masalah kehidupan sehari-hari. Selain itu subjek ST juga mampu menggunakan ide fisika yakni konsep kecepatan dalam penyelesaian masalah real-world context. Subjek ST menjawab keseluruhan tes yang diberikan dengan benar.

Dari hasil wawancara menunjukkan bahwa subjek ST memiliki kemampuan mengenali dan mengkaitkan antara ide-ide geometri dalam pemecahan masalah abstract context. Subjek ST menggunakan konsep teorema Pythagoras dalam pemecahan masalah nomor 1. Selain itu subjek ST juga mampu menggunakan konsep matematika dan fisika dalam penyelesaian masalah realworld context, yaitu konsep keliling lingkaran dan kecepatan dalam bidang Fisika. Berikut disajikan kutipan wawancara dengan subjek ST.

$P \quad:$ Apa yang anda ketahui dari soal nomor 1?

ST : Itu kan ada lingkaran di dalamnya ada segitiga siku-siku nah pertanyaanya disuruh nyari keliling dari segitiga siku-siku sama luas daerah yang diarsirkan sisi miringnya itu $20 \mathrm{~cm}$ dan alasnya $16 \mathrm{~cm}$ dan yang belum diketahui itu BA atau tingginya, untuk mencari phytagoras itu pakai phytagoras, pakai kuadratkuadrat itu

$P \quad$ : Bagaimana mencari tingginya?

ST : Untuk jawabannya tingginya itu kan kuadrat dari c atau sisi miringnya dan alasnya a itu rumusnya $b^{2}=c^{2}-a^{2}$

$P \quad:$ Kemudian ketemu berapa hitungannya?

$S T: 12$, tingginya 12

$P \quad$ : Selanjutnya cari apanya?

$S T$ : Keliling segitiga, berarti kan $a+b+c$ itu $12+20+16=48 \mathrm{~cm}$ 
$P \quad:$ Selanjutnya, apa yang anda pahami dari soal nomor $1 b$ ?

$S T$ : terus kalau yang b itu kan nyari objek yang diarsir, untuk mencari objek yang diarsir itu kita harus cari utuhnya terus dikurangi yang di dalamnya atau segitiga siku-siku tadi

$P \quad$ : selanjutnya bagaimana?

ST : jadi kan luas lingkaran rumusnya $\pi r^{2}$ untuk $\pi$ pakai 3,14 karena 10 bukan kelipatan 7 sehingga pakai 3,14

$P \quad$ : bisa dapat 10 darimana?

ST : saya dapat $r=10$ karena $20: 2$ kan tadi disoal pertama itu sudah ditulis kalau sumbu sisi miringnya mengenai panjang lingkarannya dan tepat ditengahtengah jadi kalau sisi miringnya 20 berarti rusuknya 10!

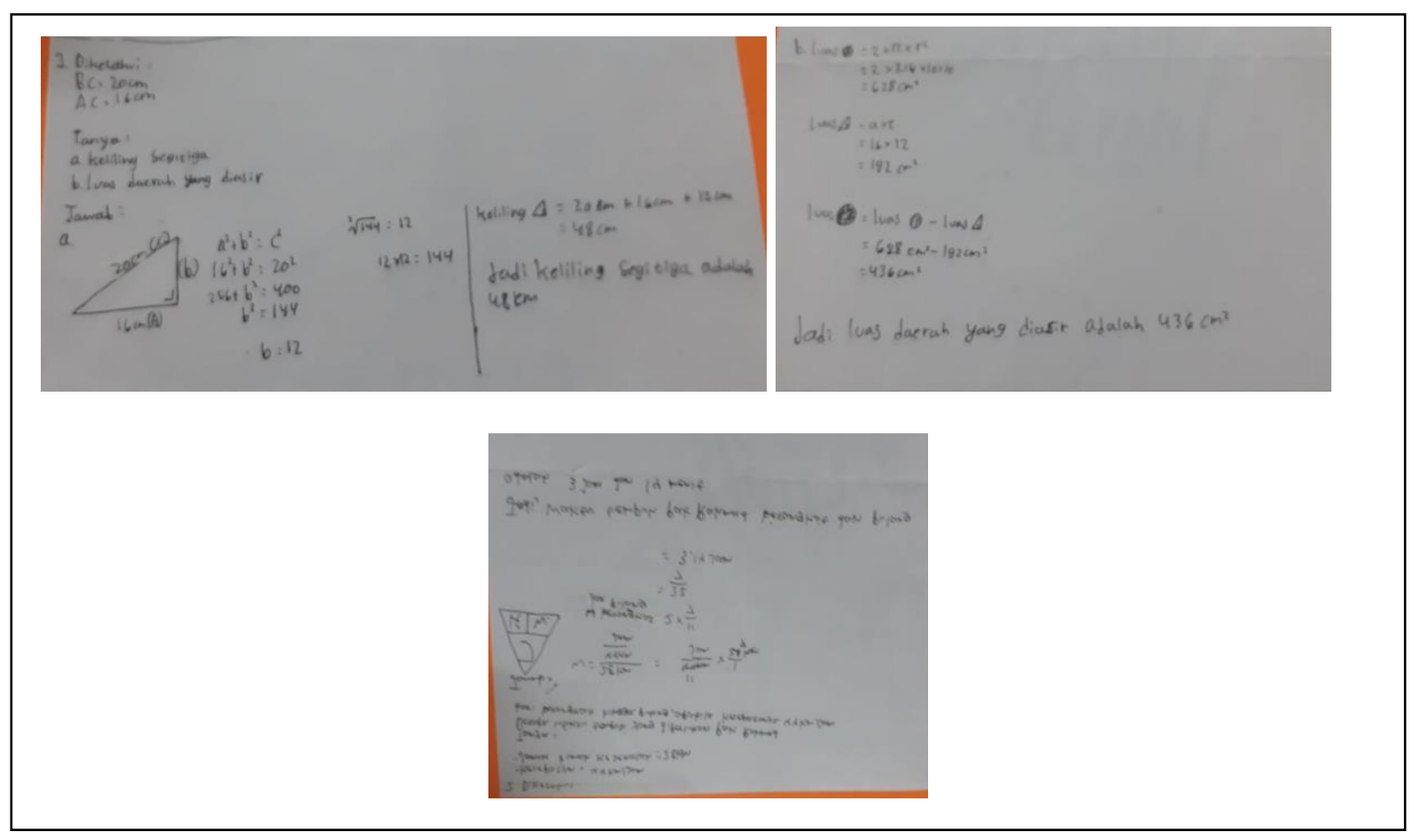

Gambar 4. Hasil Jawaban Tes Tertulis Subjek SS

Dari Gambar 4., menunjukkan bahwa pada tes tertulis subjek SS mampu mengenali ide-ide matematika yang ditunjukkan dengan kemampuannya menggunakan beberapa ide dalam penyelesaian masing-masing soal. Namun subjek SS belum maksimal dalam menghubungkan antara ide-ide matematika tersebut dalam penyelesaian soal bertipe visual problem dengan abstract content. Pada tipe soal tersebut, subjek SS menggunakan konsep luas daerah segitiga dan lingkaran namun rumus yang digunakan belum tepat. Sedangkan pada tipe soal real-world context, subjek SS tidak mampu menerapkan ide-ide matematika untuk penyelesaiannya. Hal ini terlihat dari jawaban SS pada soal nomor 2 seperti pada Gambar 4 di atas, subjek hanya membuat perbandingan dari data-data yang diberikan pada soal. Kemampuan subjek SS memahami soal juga kurang, subjek SS tidak mampu mengoptimalkan semua informasi yang diberikan pada soal, dan subjek SS mengabaikan informasi visual yang disajikan. Subjek SS tidak mampu menerapkan konsep lingkaran dalam penentuan jarak rumah ke sekolah, sehingga jawaban subjek SS keliru meskipun subjek SS telah menggunakan konsep kecepatan.

Hasil wawancara dengan subjek SS diperoleh informasi bahwa subjek SS kurang berhasil dalam mengenali ide-ide matematika dan mengkoneksikan antar ide-ide matematika seperti ide tentang luas permukaan lingkaran dan segitiga. Subjek SS tidak menyadari rumus luas daerah segitiga dan lingkaran yang digunakannya keliru. Hal ini berakibat pada hasil pekerjaannya untuk 
soal nomor 1 salah. Sedangkan pada soal nomor 2, subjek SS juga gagal menggunakan ide matematika dalam pemecahan masalah bertipe visual problem dengan real-world context. Subjek SS tidak mampu memahami soal nomor 2 dengan baik, subjek hanya memahami ada kecepatan dari rumah Pak Rahmat ke sekolah tetapi beliau gagal memahami rutenya. Sebagaimana kutipan wawancara dengan subjek SS berikut ini.

$P \quad$ : Untuk nomor 2, apa yang anda pahami?

SS : Saya tidak paham sama sekali apa maksudnya

$P \quad:$ Kemudian yang anda ketahui dari nomor 2 apa aja?

SS : Yang saya ketahui adalah kecepatannya pak rahmat dari rumah ke sekolah hingga balik kecepatannya $44 \mathrm{~km} / \mathrm{jam}$, dan kalau saya lihat juga jarak antar rumah ke sekolah $28 \mathrm{~km}$

$P \quad$ : Apakah sepemahaman anda pada gambar itu jalannya lurus?

SS : Iya

$P \quad$ : Jika dilihat dari hasil jawaban anda untuk rumusnya dapat darimana?

SS : Cara menjawab saya? Atau bagaimana?

$P \quad$ : Iya cara menjawabnya,

SS : Jarak, kecepatan, waktu, saya belajar itu disekolahan

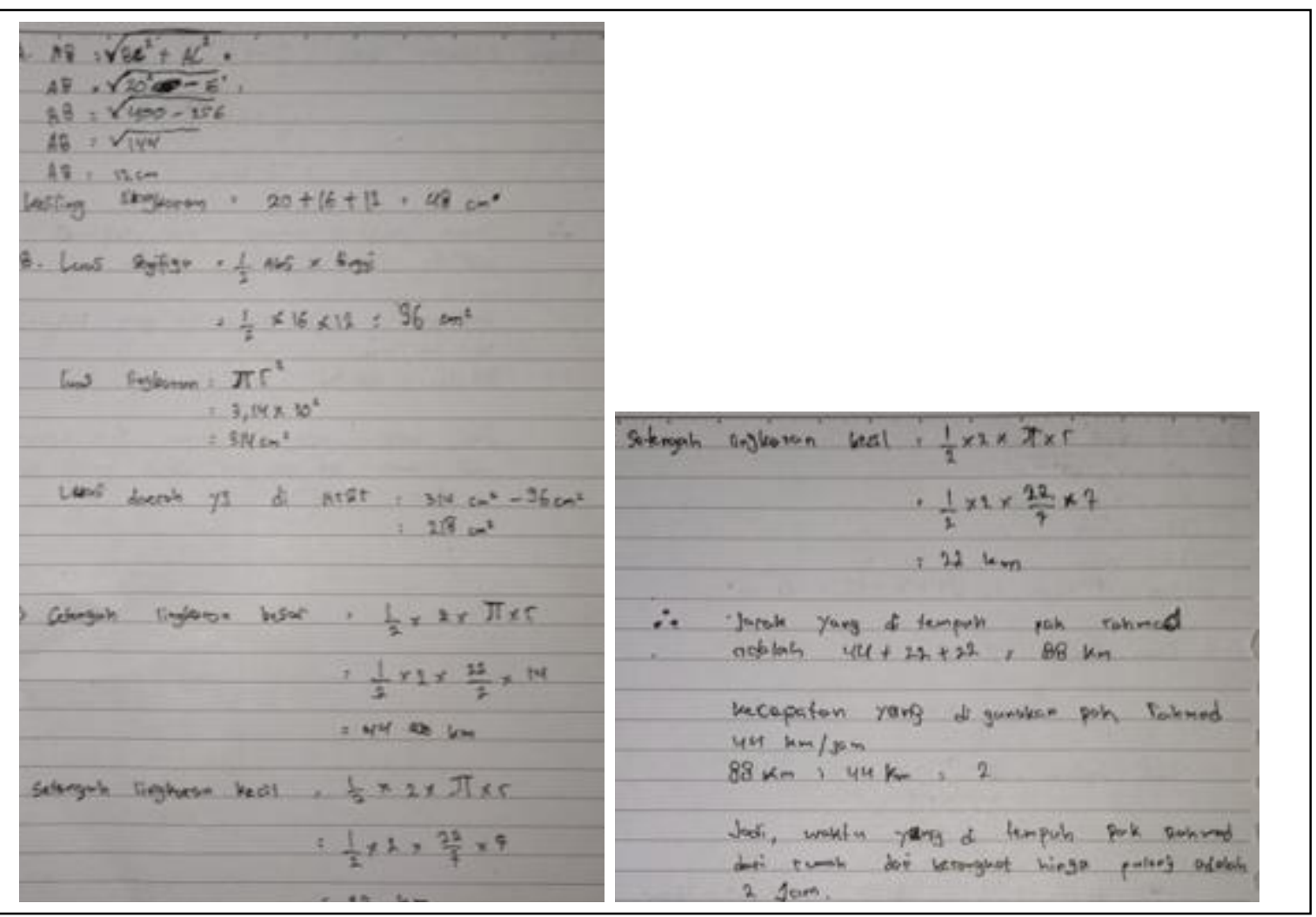

Gambar 5. Hasil Jawaban Tes Tertulis Subjek SR

Pada penyelesaian soal tes koneksi matematis sebagaimana disajikan pada Gambar 5., subjek SR mampu mengenali dan menghubungkan ide-ide geometri berupa konsep segitiga dan lingkaran dengan baik. Subjek SR mampu memahami soal dengan baik dan menggunakan konsep Toerema Pythagoras, keliling segitiga, luas daerah segitiga dan lingkaran dalam pemecahan masalah abstract context sebagaimana pada soal nomor 1 . Begitu juga pada soal bertipe visual problem dengan real-world context, subjek SS mampu memahami soal dengan baik. Hal ini ditunjukkan dengan kemampuan subjek SR menerapkan ide-ide matematika dalam pemecahan masalah yang terkait dunia nyata. Subjek SR menggunakan konsep keliling lingkaran untuk mencari rute dari 
rumah pak Rahmat ke sekolah dan selanjutnya dicari kecepatannya menggunakan rumus kecepatan yang ada di pelajaran Fisika.

Pada saat wawancara dengan subjek SR diperoleh informasi bahwa subjek SR mampu mengenali dan mengoneksikan antar ide-ide matematika untuk mengerjakan soal bertipe visual problem dengan abstract context. Subjek SR mampu memahami semua soal yang diberikan. Subjek SR menggunakan konsep teorema Pythagoras untuk mencari tinggi salah satu sisi segitiga yang belum diketahui ukurannya. Selain itu, dia juga mampu menerapkan rumus keliling segitiga, luas daerah segitiga dan lingkaran dalam menemukan jawaban. Subjek SR juga mampu mengaplikasikan ide matematika dalam pemecahan masalah terkait kehidupan nyata sebagaimana pada soal nomor 2. Dari wawancara diketahui bahwa pada awalnya subjek SR bingung dengan visualisasi denah rumah pak Rahmat, namun setelah mencermati dan memahami redaksi soal dan ilustrasi gambar, subjek SR menyatakan bisa memahami dan mengerjakan soalnya dengan baik. Kutipan wawancara dengan subjek SR disajikan sebagai berikut.

$P \quad$ : Untuk nomor 2 ya, apakah anda paham apa yang diminta pada soal nomor 2?

SR : Itu kan diminta mencari waktu yang ditempuh pak rahmat dari rumahsekolah atau dari berangkat - pulang

$P \quad$ : Langkah pertama yang anda cari apanya?

SR :Pertama mencari keliling setengah lingkaran yang besar itu,

$P \quad$ : Anda mencarinya bagaimana?

SR : Pakai rumus setengah keliling lingkaran $\frac{1}{2} \times 2 \times \pi \times r$, dapatnya $44 \mathrm{~km}$

$P \quad$ : Setelah itu yang anda cari apa?

$S R \quad$ :Terus dicari setengah lingkaran kecilnya itu dapet $22 \mathrm{~km}$, kan ada 2 yang setengah lingkaran itu, nah itu sama hasilnya $22 \mathrm{~km}$

$P \quad:$ Anda mencarinya bagaimana?

SR : Sama pakai rumus setengah lingkaran

\section{PEMBAHASAN}

Dari pengambilan data hasil tes tertulis soal kemampuan koneksi matematis dan wawancara dari masing-masing subjek penelitian, kemudian data dari kedua metode pengumpulan data itu disandingkan. Berdasarkan hasil penelitian tersebut diperoleh triangulasi teknik yang disajikan pada Tabel 1.

\section{Tabel 1. Triangulasi Teknik Data Penelitian}

\begin{tabular}{clrlrlr}
\hline Subjek & \multicolumn{2}{c}{ Tes Tertulis } & \multicolumn{2}{c}{ Wawancara } & \multicolumn{2}{c}{ Triangulasi Teknik } \\
\hline ST & Subjek ST mampu & Subjek ST & mampu & Subjek & ST & mampu \\
& mengenali & dan & mengenali & dan & mengenali & dan \\
& menghubungkan antar & menghubungkan antar & menghubungkan antar ide \\
& ide matematika, serta & ide matematika, serta & matematika, & serta \\
& mampu menerapkan & menerapkan & ide & menerapkan & ide \\
& ide matematika dalam & matematika & dalam & matematika & dalam \\
& pemecahan masalah & pemecahan masalah & pemecahan masalah dalam \\
& dalam & kehidupan & dalam & kehidupan & kehidupan nyata & \\
& nyata & & nyata & & & \\
SS & Subjek SS mengenali & Subjek SS mengenali & Subjek SS mengenali dan \\
& dan menghubungkan & dan menghubungkan & menghubungkan antar ide \\
& antar ide matematika & antar ide matematika & matematika namun belum \\
& namun & belum & namun & belum & lengkap. Subjek SS belum \\
\hline
\end{tabular}




\begin{tabular}{rlrlrlr}
\hline Subjek & \multicolumn{2}{c}{ Tes Tertulis } & \multicolumn{2}{c}{ Wawancara } & \multicolumn{2}{c}{ Triangulasi Teknik } \\
\hline & lengkap. Subjek SS & lengkap. Subjek SS & mampu mengaplikasikan \\
& belum & mampu & belum & mampu & ide matematika dalam \\
& mengaplikasikan ide & mengaplikasikan ide & kehidupan sehari-hari \\
& matematika dalam & matematika dalam & & & \\
& kehidupan sehari-hari & kehidupan sehari-hari & & & \\
SR & Subjek SR mampu & Subjek SR mampu & Subjek SR & mampu \\
& mengenali & dan & mengenali & dan & mengenali & dan \\
& menghubungkan antar & menghubungkan antar & menghubungkan antar ide \\
& ide matematika serta & ide matematika serta & matematika & serta \\
& mengaplikasikan ide & mengaplikasikan ide & mengaplikasikan & ide \\
& matematika dalam & matematikardalam & matematika & dalam \\
& kehidupan sehari-hari & kehidupan sehari-hari & kehidupan sehari-hari \\
\hline
\end{tabular}

Sumber: diolah dari data penelitian, 2020

Hasil penelitian yang diperoleh dari triangulasi teknik sebagaimana disajikan pada Tabel 1., menunjukkan bahwa subjek ST dan SR mampu mengenali dan mengkoneksikan antar ide matematika serta mengaplikasikan ide matematika dalam kehidupan sehari-hari. Sedangkan subjek SS mengenali dan menghubungkan antar ide matematika namun belum lengkap, dan belum mampu mengaplikasikan ide matematika dalam kehidupan sehari-hari. Persentase kemampuan koneksi matematis subjek penelitian berdasarkan kategori kecerdasan intrapersonalnya disajikan dalam bentuk diagram seperti pada Gambar 6.

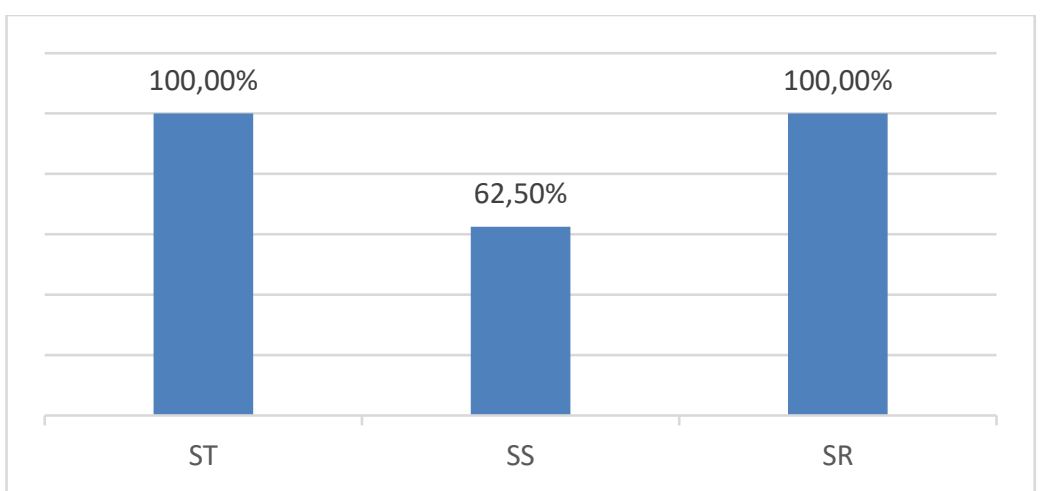

Gambar 6. Kemampuan Koneksi Matematis Subjek Penelitian

Berdasarkan paparan hasil penelitian menunjukkan bahwa terdapat perbedaan kemampuan koneksi matematis siswa dalam memecahkan masalah geometri yang dilakukan oleh ketiga subjek penelitian dengan kategori kecerdasan intrapersonal tinggi, sedang, dan rendah. siswa dengan kecerdasan intrapersonal tinggi dan rendah mampu mengenali dan mengkoneksikan antara ide matematika serta mengaplikasikan ide matematika dalam penyelesaikan masalah dunia nyata. Sedangkan siswa berkecerdasan intrapersonal sedang memiliki kemampuan mengenali dan menghubungkan antar ide matematika dalam penyelesaian soal dengan jenis abstract context yang belum lengkap. Begitu juga dalam menyelesaikan soal bertipe visual problem dengan real-world context, siswa berkategori sedang masih belum mampu mengkoneksikan ide matematika dengan bidang lain maupun dengan kehidupan sehari-hari. Dengan demikian, siswa yang memiliki kecerdasan intrapersonal tinggi dan rendah memiliki kemampuan koneksi matematis setara yang dibuktikan dengan kemampuannya memenuhi seluruh indikator kemampuan koneksi matematis. Sedangkan siswa dengan kecerdasan intrapersonal sedang hanya mampu memenuhi satu indikator koneksi matematis.

Dari Gambar 6., menunjukkan bahwa ternyata siswa dengan kecerdasan intrapersonal tinggi dan rendah cenderung memiliki kemampuan koneksi matematis lebih baik dari pada siswa dengan kecerdasan intrapersonal sedang. Hal ini dapat disebabkan oleh banyak faktor, di antara dugaan 
faktor penyebabnya adalah kemampuan matematika siswa, perkembangan berpikir geometri siswa, dan penalaran spasial siswa. Pada penelitian ini, pemilihan subjek tidak mempertimbangkan kemampuan matematika siswa sehingga dimungkinkan terjadi kondisi siswa dengan kecerdasan intrapersonal rendah yang dipilih sebagai subjek penelitian justru memiliki kemampuan matematika lebih baik dari pada siswa terpilih di kategori sedang. Dugaan ini didasarkan dari temuan penelitian Widarti (2019) dan Aviyanti dan Setianingsih (2020) yang menyebutkan bahwa siswa dengan kemampuan matematika tinggi mampu memenuhi seluruh indikator koneksi matematis.

Faktor kedua yang diduga menyebabkan siswa berkecerdasan intrapersonal sedang justru memiliki kemampuan koneksi matematis lebih rendah dari pada siswa berkecerdasan intrapersonal rendah yaitu tingkat perkembangan berpikir geometri. Hal ini dilatarbelakangi oleh materi yang digunakan dalam penelitian ini adalah segitiga dan lingkaran. Perkembangan berpikir geometri siswa dapat dilihat dari level berpikir geometri berdasarkan Teori Van Hie dengan le (Fitriyani et al., 2018). Sementara dari ketiga siswa terpilih sebagai subjek penelitian, belum diketahui perkembangan berpikir geometrinya. Ada kemungkinan siswa yang memiliki kecerdasan intrapersonal rendah justru memiliki level berpikir geometri yang lebih baik dari pada siswa yang memiliki kecerdasan intrapersonal sedang. Begitu juga dengan siswa berkecerdasan intrapersonal tinggi.

Faktor ketiga yang diduga menjadi penyebab siswa dengan kecerdasan intrapersonal kategori rendah justru lebih unggul kemampuan koneksi matematisnya dari pada siswa pada kategori sedang adalah kemampuan penalaran spasial siswa. Dugaan ini didasarkan dari pendapat Fitriyani, Kusumah dan Turmudi (2021) yang menyatakan bahwa kemampuan penalaran spasial merupakan kemampuan penalaran yang diperlukan dalam geometri yang membantu siswa memahami konsep geometri dan penyelesaian masalah sehari-hari yang melibatkan aplikasi konsep geometri. Dengan melihat tipe dan jenis soal tes koneksi matematis yang digunakan dalam penelitian ini, yaitu tipe visual problem dengan abstract context dan real-world context semakin memperkuat dugaan bila kemampuan penalaran spasial siswa ikut andil pada temuan hasil penelitian ini. Ada kemungkinan siswa terpilih kecerdasan intrapersonal kategori rendah memiliki kemampuan penalaran spasial lebih baik dari pada siswa terpilih dari kecerdasan intrapersonal kategori sedang. Begitu pun dengan siswa kategori tinggi.

Hasil penelitian ini mengindikasikan bahwa perbedaan kategori kecerdasan intrapersonal siswa tidak berbanding lurus dengan kemampuan koneksi matematis siswa. Hal ini terlihat dari siswa dengan kategori kecerdasan intrapersonal rendah memiliki kemampuan koneksi matematis lebih baik dari pada siswa yang memiliki kecerdasan intrapersonal sedang. Berdasarkan teori kecerdasan intrapersonal maka dapat dipahami bahwa semakin tinggi kecerdasan intrapersonal siswa seharusnya kemampuan memahami dan mengenali potensinya akan semakin baik pula. Sehingga diharapkan akan memberikan dampak dalam kemampuannya memaksimalkan potensi diri untuk mengkoneksikan antar ide matematika maupun di luar bidang matematika. Namun ternyata hasil penelitian ini menunjukkan temuan yang berbeda. Kemampuan koneksi matematis merupakan bagian dari aspek kognitif. Sehingga hasil temuan ini bisa dikatakan bahwa perbedaan tingkat kecerdasan intrapersonal siswa tidak terkait dengan tingkat kemampuan kognitif siswa.

Dari paparan hasil penelitian dan dugaan-dugaan atas penyebab dari temuan penelitian maka perlu adanya penelitian lanjutan jika ingin mengetahui secara ilmiah hubungan antara kecerdasan intrapersonal dan kemampuan koneksi matematis. Selain itu, hubungan antara kemampuan matematika, perkembangan berpikir geometri dan kemampuan penalaran spasial siswa dengan kemampuan koneksi matematis siswa juga tak kalah menarik jika ingin dikaji lebih jauh. 


\section{SIMPULAN}

Siswa dengan kecerdasan intrapersonal berbeda menunjukkan kemampuan koneksi matematis yang berbeda juga. Siswa dengan kecerdasan intrapersonal tinggi dan rendah mampu memenuhi seluruh indikator koneksi matematis yakni mengenali dan menghubungkan di antara ide-ide matematika, dan mengaplikasikan ide-ide matematika dalam kehidupan sehari-hari. Sedangkan siswa dengan kecerdasan intrapersonal sedang hanya mampu memenuhi satu indikator koneksi matematika yakni mengenali dan menghubungkan antar ide-ide matematika namun belum lengkap. Kemampuan koneksi matematis siswa yang memiliki kecerdasan intrapersonal tinggi dan rendah lebih baik dari pada siswa dengan kecerdasan serupa namun kategori sedang. Temuan penelitian ini mengindikasikan bahwa kategori kecerdasan intrapersonal siswa tidak berbanding lurus dengan kemampuan koneksi matematis siswa.

\section{DAFTAR RUJUKAN}

Anjani, D., \& Imami, A. I. (2019). Analisis Kemampuan Koneksi Matematis Siswa SMP Pada Materi Geometri. Prosiding Seminar Nasional Matematika Dan Pendidikan Matematika Sesiomadika 2019, 158-166. https://doi.org/10.15575/ja.v6i1.8566

Apipah, S., Kartono, \& Isnarto. (2018). An analysis of mathematical connection ability based on student learning style on visualization auditory kinesthetic (VAK) learning model with selfassessment. Journal of Physics: Conference Series, 983(1). https://doi.org/10.1088/17426596/983/1/012138

Aviyanti, E. N. K., \& Setianingsih, R. (2020). Kemampuan Koneksi Matematis Peserta Didik Kelas VIII dalam Menyelesaikan Masalah Kontekstual Materi Geometri Ditinjau Dari Kemampuan Matematika. Jurnal Penelitian Pendidikan Matematika Dan Sains, 4(2), 103109.

Budiningsih, C. A. (2005). Belajar dan Pembelajaran. Rineka Cipta.

Budiyanta, E., Sutadi, L. I., \& Fitriyani, H. (2019). Identifikasi Kecerdasan Intrapersonal Siswa Kelas VIII SMP Negeri 7 Yogyakarta. Prosiding Sendika, 5(1), 530-533. http://eproceedings.umpwr.ac.id/index.php/sendika/article/view/796

Burte, H., Gardony, A. L., Hutton, A., \& Taylor, H. A. (2020). Elementary teachers' attitudes and beliefs about spatial thinking and mathematics. Cognitive Research: Principles and Implications, 5(1). https://doi.org/10.1186/s41235-020-00221-w

Fitriyani, H., Kusumah, Y. S., \& Turmudi, T. (2021). Spatial Reasoning: A Survey on the 8th Grader Students' Gain in Online Learning. International Journal on Emerging Mathematics Education, 5(1), 51-60. https://doi.org/10.12928/ijeme.v5i1.20140

Fitriyani, H., Setyawan, F., Hendroanto, A., \& Istihapsari, V. (2021). Describing student's mathematical power: Do cognitive styles make any difference? Bulletin of Applied $\begin{array}{lllll}\text { Mathematics and } \quad \text { Mathematics } & \end{array}$ https://doi.org/10.12928/bamme.v1i1.3856

Fitriyani, H., Widodo, S. A., \& Hendroanto, A. (2018). Students' Geometry Thinking based on Van Hiele's Theory. Infinity Journal, 7(1), 55-60. https://doi.org/10.22460/infinity.v7i1.p5560

Kemendikbud. (2019). Laporan Hasil Ujian Nasional. Pusat Penilaian Pendidikan Kementerian Pendidikan Dan Kebudayaan. https://hasilun.puspendik.kemdikbud.go.id/

Lestari, R. S., Rohaeti, E. E., \& Purwasih, R. (2018). Profil Kemampuan Koneksi Matematis Siswa SMP Dalam Menyelesaikan Soal Bangun Ruang Sisi Datar Ditinjau Dari Kemampuan Dasar. JIPMat, 3(1), 51-58. https://doi.org/10.26877/jipmat.v3i1.2220

Miles, M., Huberman, M., \& Saldaña, J. (2014). Qualitative Data Analysis: A Methods Sourcebook 
Thousand Oaks, CA: Sage (3rd ed.).

Muflihah, I. S., Ratnaningsih, N., \& Apiati, V. (2019). Analisis Kemampuan Koneksi Matematis Ditinjau Dari Gaya Berpikir Peserta Didik. Journal Authentic Research on Mathematics Education (JARME), 1(1), 68-77.

Mumu, J., \& Tanujaya, B. (2019). Analysis of mathematical connection in abstract algebra. Journal of Physics: Conference Series, 1321(2). https://doi.org/10.1088/1742$6596 / 1321 / 2 / 022105$

NCTM. (2000). Standards for school mathematics. The National Council of Teachers of Mathematics.

Padillah Akbar, M. B. I. S. A. A. (2018). Analisis Kemampuan Koneksi Matematis Siswa SMP pada Materi Persamaan dan Pertidaksamaan Linear Satu. Journal On Education, 01(02), 309316.

Prihastanto, A. R., \& Fitriyani, H. (2017). Profil Kemampuan Koneksi Matematis Siswa SMP yang bergaya Kognitif Reflektif-Impulsif dalam Menyelesaikan Soal Geometri. http://journal.umg.ac.id/index.php/didaktika/article/view/12

Rokhima, N., \& Fitriyani, H. (2017). Pemecahan Masalah Matematika Siswa SMP ditinjau Dari Kecerdasan Interpersonal. Seimnar Nasional Pendidikan, Sains, Dan Teknologi.

Rokhima, N., \& Fitriyani, H. (2018). Student's Metacognition : Do Intrapersonal Intelligent Make Any Difference? Mosharafa: Jurnal Pendidikan Matematika, 7(2). http://journal.institutpendidikan.ac.id/index.php/mosharafa

Romli, M. (2016). Profil Koneksi Matematis Siswa Perempuan SMA dengan Kemampuan Matematika Tinggi dalam Menyelesaikan Masalah Matematika. MUST: Journal of Mathematics Education, Science and Technology. https://doi.org/10.30651/must.v1i2.234

Siregar, R., \& Siagian, M. D. (2019). Mathematical connection ability: Teacher's perception and experience in learning. Journal of Physics: Conference Series, 1315(1). https://doi.org/10.1088/1742-6596/1315/1/012041

Widarti, A. (2019). Kemampuan Koneksi Matematis dalam Menyelesaikan Masalah Kontekstual Ditinjau dari Kemampuan Matematis Siswa. JIPMat, 1(1), 72-79. https://doi.org/10.26877/jipmat.v3i1.2220

Zuyyina, H., Wijaya, T. T., P, H. M., \& Senjawati, E. (2018). Kemampuan Koneksi Matematis Siswa SMP pada Materi Lingkaran. SOSIOHUMANIORA: Jurnal Ilmiah Ilmu Sosial Dan Humaniora, 4(2), 79-90. https://doi.org/10.30738/sosio.v4i2.2546 